郎ち

$$
\left(C_{p}+\frac{R}{d u w}\right) \frac{d T}{T}=\frac{R}{p} d p
$$

を得る、之を積分すれば

郎亏

$$
\begin{aligned}
& T^{C_{p}+\frac{K}{a w}} p^{-R}=\text { const } \\
& T p^{-R / O_{p}+\frac{K}{a w}}=\text { const }
\end{aligned}
$$

になり，之を $(3 \cdot 9)$ とを比較すれば

$$
\frac{1}{k}-1=-R / C_{p}+\frac{K}{\alpha w}
$$

師ち

$$
k=1 / 1-\frac{R}{C_{p}+\frac{K}{\alpha w}}=\frac{C_{p}+\frac{K}{\alpha w}}{C_{p}-R+\frac{K}{w \alpha}}=\frac{C_{p}+\frac{K}{\alpha w}}{C_{v}+\frac{K}{\alpha w}}
$$

を得る。

此の場合 $K=0$ とすれば $k=C_{p} / C_{v}$ 即ち斷熱變化， $\alpha$ 又は $w$ が筞に近いか $K$ が非常に大きい 場合 $K=1$ になり等盢變化沉なる.

\title{
垂直線偏倚より見た本邦近傍地殼均衡面の深さに就いて*
}

$$
\text { 川畑幸夫, 鮎田正 }
$$

1. 緒 言 本邦は四面海に圍まれて居り，日本弧岛其れ自身は世界中で最も著明な地震帶に沿 ふて居る.そればかりで無く,和澾博士に依つて發見せられた深弡地震帶は本邦を伊勢灣近傍で横斷

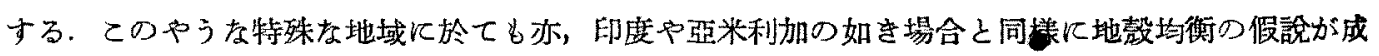
立するであらうかといふことは地球物理學的に見て一つの重要な研究項目である. 若し假に斯くの 如き幾巧が成立して居るとすれば,次に其の深さは幾何かといふ問題が起るであらう.元來本邦の如

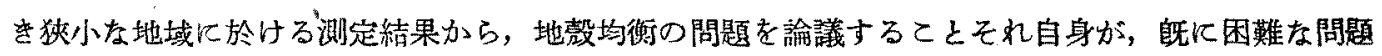
であり，從つて更に進んで均衡面の樑さを求めるととは更に图難なととであるのは言ふ迄もない. 地球物理學的に考入て見ても, 均衡面といふ一つの確然たる不連緮面狀のるのが存在するわけでは 在い，然しともかく，在來の意義の均衡面が，深いか或は淺いかといふととは或種の地款性狀を表示 してるるととには間違が無く, 殊に地下に於ける犁は可成の程度迄彈性によつて支へられてるると

* Y. Kawabata, T. Ayuda: Depth of Isqstatic Compensation view from the Deflections of the

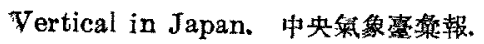


は言人，兩者の間にはそれ相應の相違が存在する筈である。

從來本邦に於ても均衡面の深さを求めんとする試みは若干行はれたてとがある，就中熊谷博士り， は海洋に於ける重力測定の結果から其の深さを $170 \mathrm{~km}$ と推定せられ看．從來の概念儿從へば非常

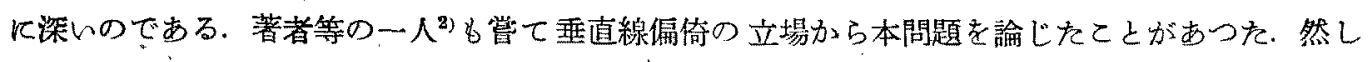
當時計算が充分進行してるなかつた縓に, 使用した觀測材料が少く, 充分几信賴することは出爽 ない狀態であつを. 其の後更に，計算を續行し若干の觀測を追加することが出來をので其の結果を 茲に報告して置き度いと思宗。

2. 地形の補正 地形に团る引力補正の計算方法は前諭文に詳遮し置きたる老以て，站に改めて

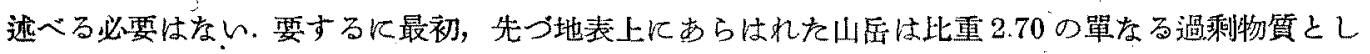
て平均海面上使つかつて居り，又海洋の部分では比重が岩石之海水の密度差 $2.70-1.03=1.67 \mathrm{~K}$ 相當する缺損物質が存在すると考人て觀測點から周圍 $936 \mathrm{~km}$ の篹圍內にある地形に基く引力を子 午線成分及び本行圈成分の各タについて計算し，之れを垂直線偏倚に換算して實測值を補正するの である. 從つて斯くして補正せる垂直線偏倚は觀测點を中心として海面高零支る平原が涯しもをく 擴がつて居り，且つ地下の密度が一定なるものと考へた場合に，賽測せらるべき偏倚量を示すのであ る. 地下に於ける密度が此の假定の通り一定であるならば地形補正をなせる垂直線偏倚は偶然的分 布をなすべき筈であり，又若し，補正し過ざを結果となれば， 地殼は均衡の狀態にあると推定せられる.ヴェクトルの如ぐ 見做した此の残存偏倚量と地形との相關程度は同時に又均衡 狀態の良否を判斷する目安を與入る筈である。計算の手暊を 極くざつと說明すれば次の通りである（記號其の他すべて 前論文索照せられ度い).

地形に因つて，觀測點を通る鉊直線ば

$$
\delta A n_{0}{ }^{\prime}=\delta A h_{n_{0}} / \sqrt{1+\frac{h_{0}}{R}+\frac{h_{0}{ }^{2}}{R^{2}}}
$$

なる水平引力を受ける。但し $\delta A h_{0}{ }^{\prime}$ 壮

$$
\begin{aligned}
\delta A_{k_{0}}{ }^{\prime} & =f \frac{\dot{R}^{2} \rho_{0} \cos \frac{\alpha}{2} d \omega}{D^{2}} h_{0} \\
& =f \rho_{0} h_{0}\left(\sin \beta_{k}-\sin \beta_{i}\right)\left(\log \frac{a_{k}}{a_{i}}-\frac{5}{48} \frac{a_{\mathrm{x}}{ }^{2}-a_{i}^{2}}{R^{2}}\right)
\end{aligned}
$$

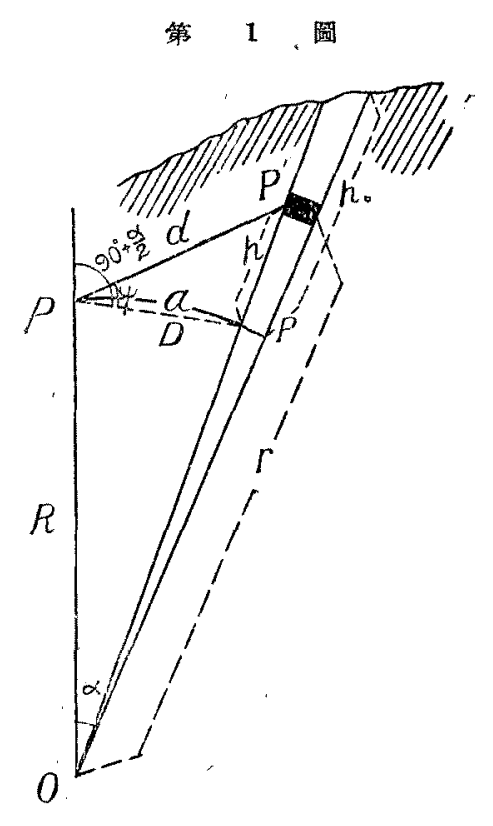

1) Rep. Imp. Jap. Geod. Comm. No. XI.

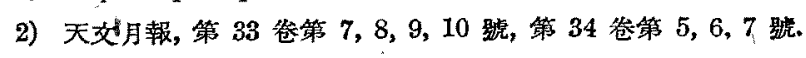




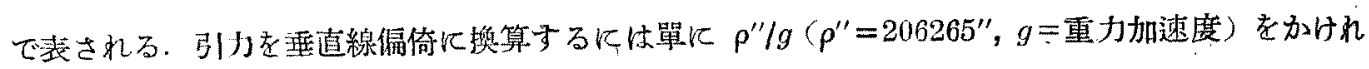
ばよい。

計算の便宜のため，觀測點を中心として全地域を第2圖の如く分割する，方向線は $\sin \beta_{k}-\sin \beta_{i}$ が恰度 0.25 上なるように引いてあり，又同心 第 2 圆

圓の牛經は（2）の最後の項 $\log \frac{a_{k}}{a_{\imath}}-\frac{5}{48} \frac{a_{x}^{2}-a^{2}}{\mathrm{R}^{2}}$ が 0.5263 となるように分けてある。このように 分割すると觀測點が海面高零の高さにあるとき は（2）は陸地の各分劃に對しては

$\delta A_{h_{0}}{ }^{\prime}= \pm 0^{\prime} .0050 h_{0} \quad\left(h_{0}\right.$ は米突單位 $)$

となる、觀測點の周圍の全面積に對する補正 は，此等老總和すればよい。

$$
\sum \delta A_{\mathbf{u}_{0}{ }^{\prime}}= \pm 0^{\prime \prime} .0050 \sum h_{0}
$$

$h_{0}$ 注各分劃队の平均高度 (米)で秀つて，(3) の符號は原方向の存在する牛面側が正で他面が 負である（3）を(2)に代大すれば全地域の補 正偏倚量汃得られる。

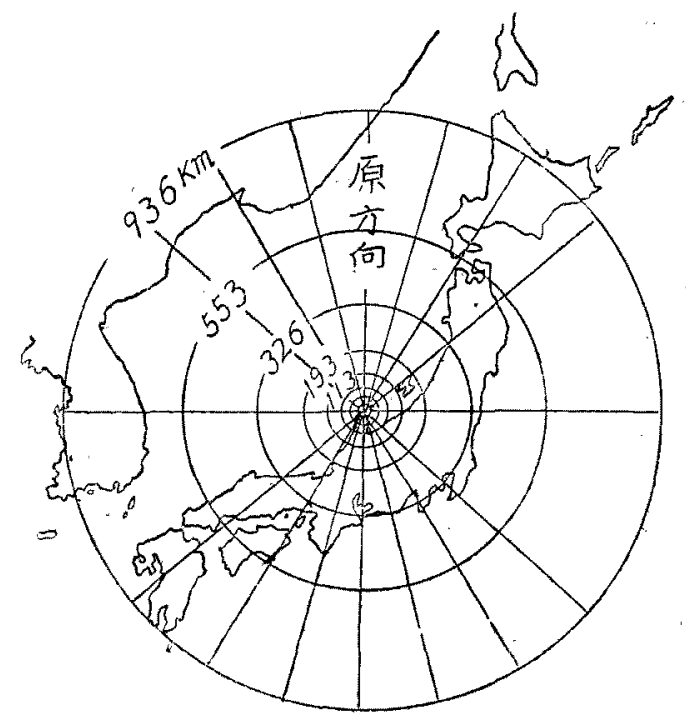

海洋部分の引力子全く同樣にして求められる. 郎ち海水の比重索 1.03 岩石の本均比重を 2.70 と し，結局 2.70-1.03 考る比重の缺損物質があるとすれば

$$
\sum \delta A_{h_{0}}{ }^{\prime}=\mp 0^{\prime \prime} .0031 \sum h_{0}
$$

此の場合 $h_{0}$ 㤌該分劃の平均水深（米）である.

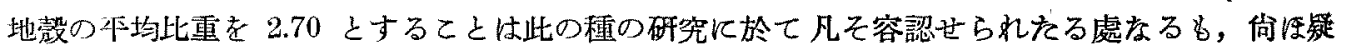

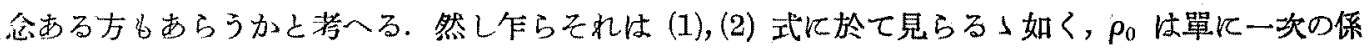
数としてかいつて居る丈けであり，從つて $(3)_{1},(3)_{2}$ に於ける $0^{\prime \prime} .0050,0^{\prime \prime} .0031$ をる值を單に多少變 更する丈けとすを゙故い。例人ば本均密度を 3.50 とすれば $0^{\prime \prime} .0050$ なる係數は $0^{\prime \prime} .0065$ となる丈け である、一方に於て次の第1表よりも推定せらる」如く，地形の補正は觀測點の極く近傍では極め て小さく，遠方の地形が大さく影響する．これは陸地の本均高度が 1000 米ともなるととは極めて 稀であるが，海の平均の哚さは通常數千米に及ぶからである. 從つて大體汇於て一一多少の變化は あるが一一 $\rho_{0}$ を多少變更しても後に述べる第 3 圖に於ける矢印の方向は殆んぞ變ら亦, 其の大きさ のみが伸縮する丈けの結果となり，吾々の將來の論議には何等不都合を來すととはないのである.

欟測點が本均海面上若干の高さ $H_{0}$ (米) にある場合には，其のために更に又上式に若干゙修正 を要する. 此の修正索行ひ且つ微小な項は省略すれば結局 


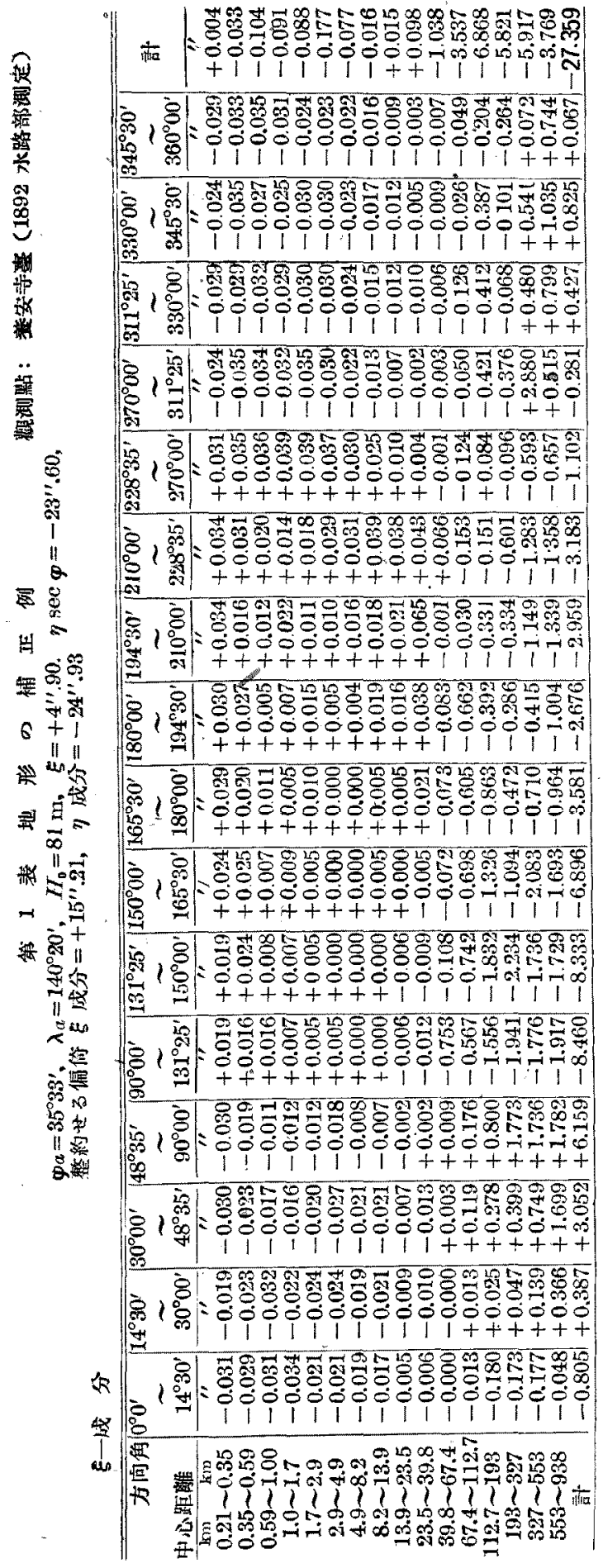

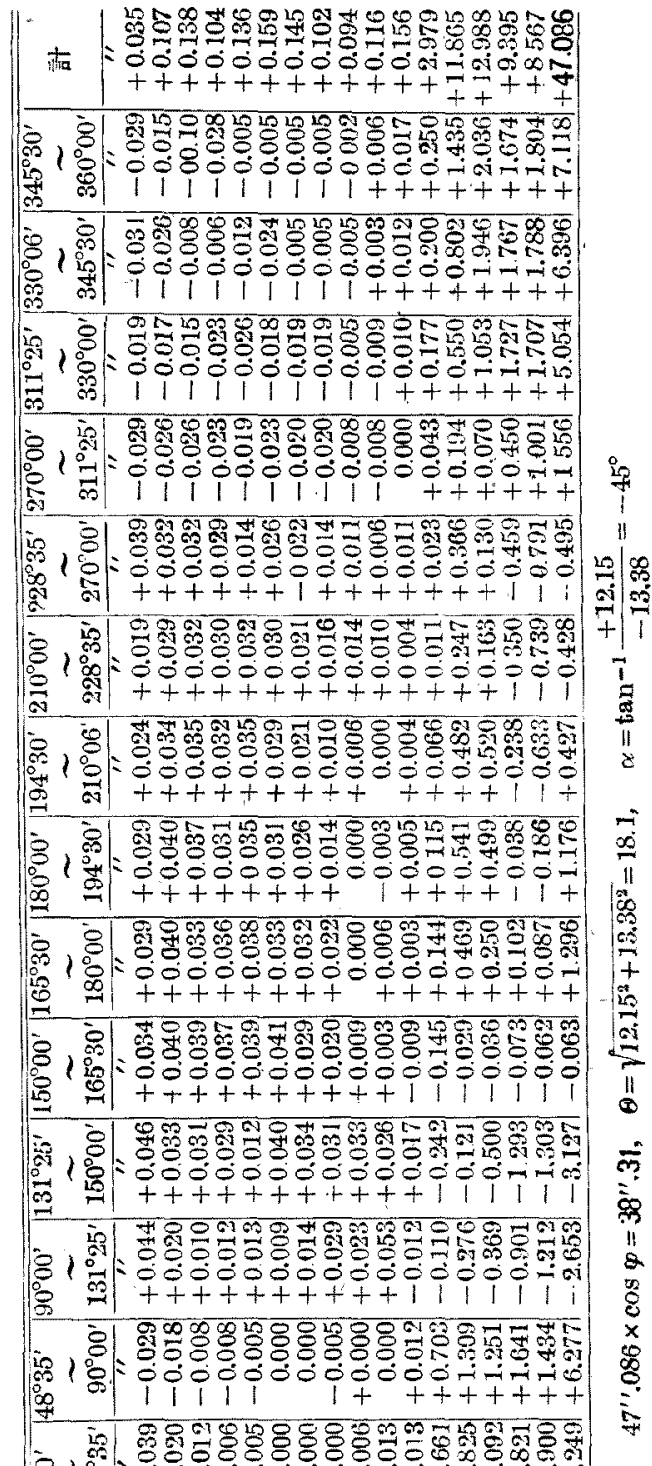

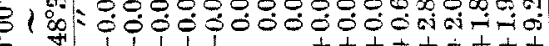
(6)

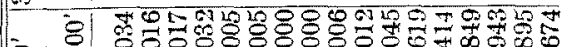
\% 10 i $00000000000-i 21$

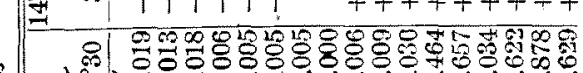

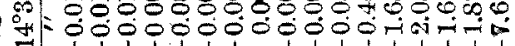
然

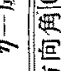
$1111111+++++++++$

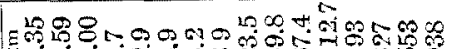

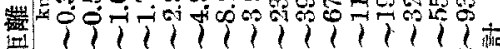

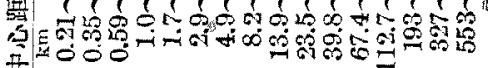




$$
\sum \Delta A h_{0}=\sum\left[\frac{h_{0}-H_{0}}{\sqrt{1+\frac{h_{0}-B_{n}}{a^{2}}}}+\frac{H_{n}}{\sqrt{1+\frac{B_{0}^{2}}{a^{2}}}}\right]^{\frac{1}{h_{0}}}
$$

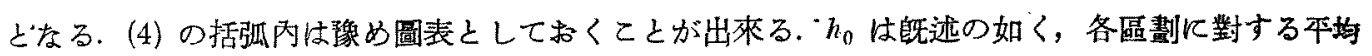
海拔或は水深であつて，地形圖，海圆を用ひて適當孝經緯度の網目を作り谷交叉點の值を讀取つて 其の本均をとるのである. これが實際上最繁雜な仕事である. 各分劃內に少くとも 10 㮯位は交 叉點が含まれるように、觀測點からの距離に應じて豫め作製せる圖を用ひた。郎ぢ1/5 萬地形圖並 亿觀測點附近の成可く詳細な海國から，經緯度备々 $15^{\prime \prime}$ 隔きの網目を作り，それで $a=1.7 \sim 4.9 \mathrm{~km}$ 艺の範圍を補正する. 同樣 $30^{\prime \prime}$ 隔きの讀取によつて $a=8.2 \mathrm{~km}$ 迄, 各 $1^{\prime}$ 每の交文點に其の中央 點の平均高によつて $13.9 \mathrm{~km}$ 迄を補正する，次に全國の $1 / 5$ 萬地形圖及び適當な海圖を撰び各 $1^{\prime}$ 隔をの交叉點の高さを讀取り，それを $1 / 20$ 萬等距投影圖上に轉記し，それに基いて $39.8 \mathrm{~km}$ 迄を

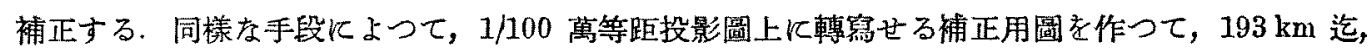
$1 / 1000$ 萬補正用圖によつて $936 \mathrm{~km}$ 迄補正する. 觀測點の極く近傍は竄真引伸价しにより，同样 な原理で補正し全地域の補正值を算出した。

一區劃中に海之陸が共存するような場合，其の他種々特殊孝場合に於ける詳細は前論文を育照せ られそい，地形の補正をなすべき地域恃どれ位の範图吾で及べばよいかといふととは難かしい問題 であるが，東に太平洋，西に日本海を有する日本のやうな場合であると，1000 km より遠方の地形 は日本內地の各觀測點に對し殆んど一定の引力を與人ることが筫祭上知られる（若干の點について 吾々は $1500 \mathrm{~km}$ まて補正して比較してみれ). 從つて $1000 \mathrm{~km}$ 以上は全體に常數を加へさへすれ ばよレやうな結果となり，而も太平洋の方が深いから $1000 \mathrm{~km}$ まで補正しさへすれば吾ねの將來 の諭議や結論は質的に何等の變更を受けをいのである.

一例として，觀測點養安寺臺飞對する地形補正の計算を揭げる (第 1 表). 實測せる垂直線偏倚

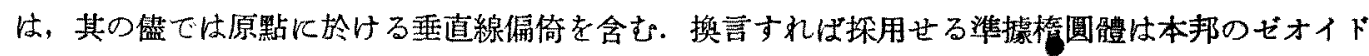
と多少の傾科を有するのである．此の倾斜を修正し，本邦に於けるゼオイドに最もよく適合する样

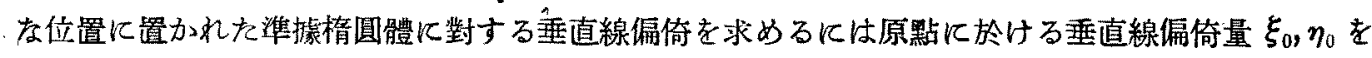
誤差方程式

$$
a \xi_{0}+b \eta_{0}=l_{1}, \quad a^{\prime} \xi_{0}+b^{\prime} \eta_{0}=l_{2}
$$

より求め，各觀測方程式に對する剩餘を算出すれ代よいのである． $l_{1}, l_{2}$ は實測垂直線偏倚量で，又 $a, b, a^{\prime}, b^{\prime}$ 等は前論文の附表を用ひる.

前論文發表以後文部省測地學委員會に於ては，更に下記 9 點に於て精密な測定を實施せられた。 
第 2 表

\begin{tabular}{|c|c|c|c|c|c|c|c|c|c|}
\hline 倠測點 & $\begin{array}{l}89^{*} \\
\text { 高㢣山 }\end{array}$ & 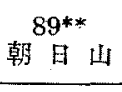 & $\begin{array}{c}109^{*} \\
\text { 島星山 }\end{array}$ & $\begin{array}{l}38^{3 *} \\
\text { 男和 } \\
\text { 羅比山 } \\
\end{array}$ & $+\stackrel{40^{*}}{\text { 二动山 }}$ & 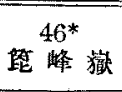 & $\begin{array}{c}99^{*} \\
\text { 尾本宫山 }\end{array}$ & 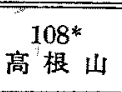 & 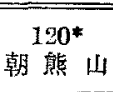 \\
\hline 位置 $\left\{\begin{array}{l}\varphi \\
\lambda\end{array}\right)$ & $\begin{array}{r}35^{\circ} 31^{\prime} \\
13415\end{array}$ & $\begin{array}{c}35^{\circ} 31^{\prime} \\
13259\end{array}$ & $\begin{array}{r}34^{\circ} 59^{\prime} \\
13214\end{array}$ & $\begin{array}{r}40^{\circ} 03^{\prime} \\
14146^{\prime}\end{array}$ & $\begin{array}{r}39^{\circ} 32^{\prime} \\
14159\end{array}$ & $\begin{array}{r}38^{\circ} 34^{\prime} \\
14110\end{array}$ & $\begin{array}{r}35^{\circ} 20^{\prime} \\
13659\end{array}$ & $\begin{array}{r}35^{\circ} 03^{\prime} \\
13657\end{array}$ & $\begin{array}{l}34^{\circ} 28^{\prime} \\
13646\end{array}$ \\
\hline $\begin{array}{l}\xi \\
\eta\end{array}$ & $\begin{array}{r}-19.13 \\
+15.21 \\
\end{array}$ & $\begin{array}{r}11 \\
-14.97 \\
+11.46\end{array}$ & $\begin{array}{r}1 \prime \prime \\
-16.48 \\
+16.04\end{array}$ & $\begin{array}{r}-20.83 \\
-13.08\end{array}$ & $\begin{array}{r}-14.11 \\
-13.19\end{array}$ & $\begin{array}{r}-11.07 \\
+\quad 5.45\end{array}$ & $\begin{array}{r}-7.94 \\
+21.70\end{array}$ & $\begin{array}{r}-11.50 \\
+20.69\end{array}$ & $\begin{array}{r}1 \prime \\
-16.60 \\
+18.97\end{array}$ \\
\hline
\end{tabular}

以上 9 點に對する觀測方程式は次の如くなる.

$$
\begin{array}{cll}
38^{*} & 0.996 \xi_{0}-0.021 \eta_{0}+20.83=0 & +0.022 \xi_{0}+0.997 \eta_{0}+13.08=0 \\
40^{*} & 0.996^{\prime \prime}-0.023^{\prime \prime}+14.11=0 & +0.024^{\prime \prime}+0.997^{\prime \prime}+13.19=0 \\
46^{*} & 0.996^{\prime \prime}-0.015^{\prime \prime}+11.07=0 & +0.015^{\prime \prime}+0.998 \prime \prime-5.45=0 \\
89^{*} & 0.994^{\prime \prime}+0.056^{\prime \prime}+19.13=0 & -0.055^{\prime \prime}+0.998^{\prime \prime}+15.57=0 \\
89^{* *} & 0.993^{\prime \prime}+0.069^{\prime \prime}+14.97=0 & -0.069 "+0.998^{\prime \prime}+12.18=0 \\
99^{*} & 0.996^{\prime \prime}+0.029^{\prime \prime}+7.94=0 & -0.028^{\prime \prime}+1.000^{\prime \prime}-21.70=0 \\
108^{*} & 0.996 "+0.029^{\prime \prime}+11.50=0 & -0.028^{\prime \prime}+1.000^{\prime \prime}-20.69=0 \\
109^{*} & 0.992^{\prime \prime}+0.077^{\prime \prime}+16.48=0 & -0.076^{\prime \prime}+0.997 "-13.50=0 \\
120^{*} & 0.997^{\prime \prime}+0.030^{\prime \prime}+16.60=0 & -0.029^{\prime \prime}+0.999 "-18.97=0
\end{array}
$$

此の 18 個の觀測方程式者前論文の觀測方程式に笺足して Normal equation

$$
12.699 \xi_{0}+2.22 \eta_{0}=-129 \dot{7}^{\prime \prime} .04,2.22 \xi_{0}+113.72 \eta_{0}=+635^{\prime \prime} .89
$$

\begin{tabular}{|c|c|c|c|c|c|c|c|}
\hline 雙 测 點 & $\left|\begin{array}{c}38^{*} \\
\text { 男和佐羅比山 }\end{array}\right|$ & 赤 40 & 十三神山 & 飯 盛山 & 篦峰葆 & 粟 $^{47}$ 島 & 松年崎 \\
\hline 位 贀 $\left\{\begin{array}{l}\varphi \\
\lambda\end{array}\right.$ & $\begin{array}{r}40^{\circ} 03^{\prime} \\
14146\end{array}$ & $\begin{array}{r}39^{\circ} 40^{\prime} \\
14004\end{array}$ & $\begin{array}{r}39^{\circ} 32^{\prime} \\
14159\end{array}$ & $\begin{array}{c}38^{\circ} 54^{\prime} \\
13949\end{array}$ & $\begin{array}{l}38^{\circ} 34^{\circ} \\
14110\end{array}$ & $\begin{array}{r}38^{\circ} 27^{\prime} \\
13914\end{array}$ & $\begin{array}{r}37^{\circ} 57^{\prime} \\
13908\end{array}$ \\
\hline $\begin{array}{r}\xi \cdots \cdots \\
\text { 地形補正 } . .\end{array}$ & $\begin{array}{r}-10.44 \\
-226\end{array}$ & $\begin{array}{r}\text { I' } \\
-2.01 \\
+\quad 1.64\end{array}$ & $\begin{array}{r}11 \\
-\quad 3.71 \\
-15.32\end{array}$ & $\begin{array}{r}11 \\
-5.19 \\
+5.67\end{array}$ & $\begin{array}{l}\quad 0.71 \\
-10.65\end{array}$ & $\begin{array}{r}1 \prime \\
-4.05 \\
+\quad 8.97\end{array}$ & $\begin{array}{r}17 \\
-6.16 \\
+\quad 7.39\end{array}$ \\
\hline$\xi^{\prime} \cdots$ & $-12,70$ & $-0,37$ & -19.03 & +0.48 & $-11,36$ & $+\underset{\not, 92}{4.92}$ & +1.23 \\
\hline$\underset{\text { 地形補正 }}{\eta \ldots .}$ & $\begin{array}{l}-18.62 \\
+33.15\end{array}$ & $\begin{array}{r}+18.05 \\
-1.90\end{array}$ & $\begin{array}{r}-18.71 \\
+37.23\end{array}$ & $\begin{array}{r}+16.83 \\
+\quad 0.50\end{array}$ & $\begin{array}{r}-0.18 \\
+27.87\end{array}$ & $\begin{array}{l}+11.41 \\
-0.73\end{array}$ & $\begin{array}{l}+14.32 \\
-052\end{array}$ \\
\hline$\eta^{\prime} \cdots$ & & +16.15 & +18.52 & $+17,33$ & $+27,69$ & $+10,68$ & $+14,84$ \\
\hline $\begin{array}{l}\theta \cdots \\
\alpha \cdots\end{array}$ & $\begin{array}{l}19.3 \\
-49^{\circ}\end{array}$ & $\begin{array}{l}16.2 \\
-89^{\circ}\end{array}$ & $\begin{array}{l}26.6 \\
-44^{\circ}\end{array}$ & $\begin{array}{l}17.4 \\
\rightarrow 92^{\circ}\end{array}$ & $\begin{array}{l}30.0 \\
-68^{\circ}\end{array}$ & $\begin{array}{r}11.7 \\
-115^{\circ}\end{array}$ & $\begin{array}{l}14.9 \\
-95^{\circ}\end{array}$ \\
\hline
\end{tabular}

を解けば

$$
\xi_{0}=-10^{\prime \prime} .31, \quad \eta_{0}=+5^{\prime \prime} .79
$$

となり，前に求めを值と殆んぎ大差は無いが，以下此の (5) を用ひて各觀測方程式から剩餘を算出 する.

斯くて全國に成るへくく觀測點が平等に分布するように26 點を撰んで地形の補正を行つを結果が 第 3 表である. 第一行の $\xi, \eta$ は上記の各觀測方程式の剩狳として求められた偏倚量で，第二行は トポグラフィーの補正量，第三行 $\xi^{\prime} ， \eta^{\prime}$ は上記二量の和で，即ち地形の補正をなせる偏筒量である. 第 3 表 


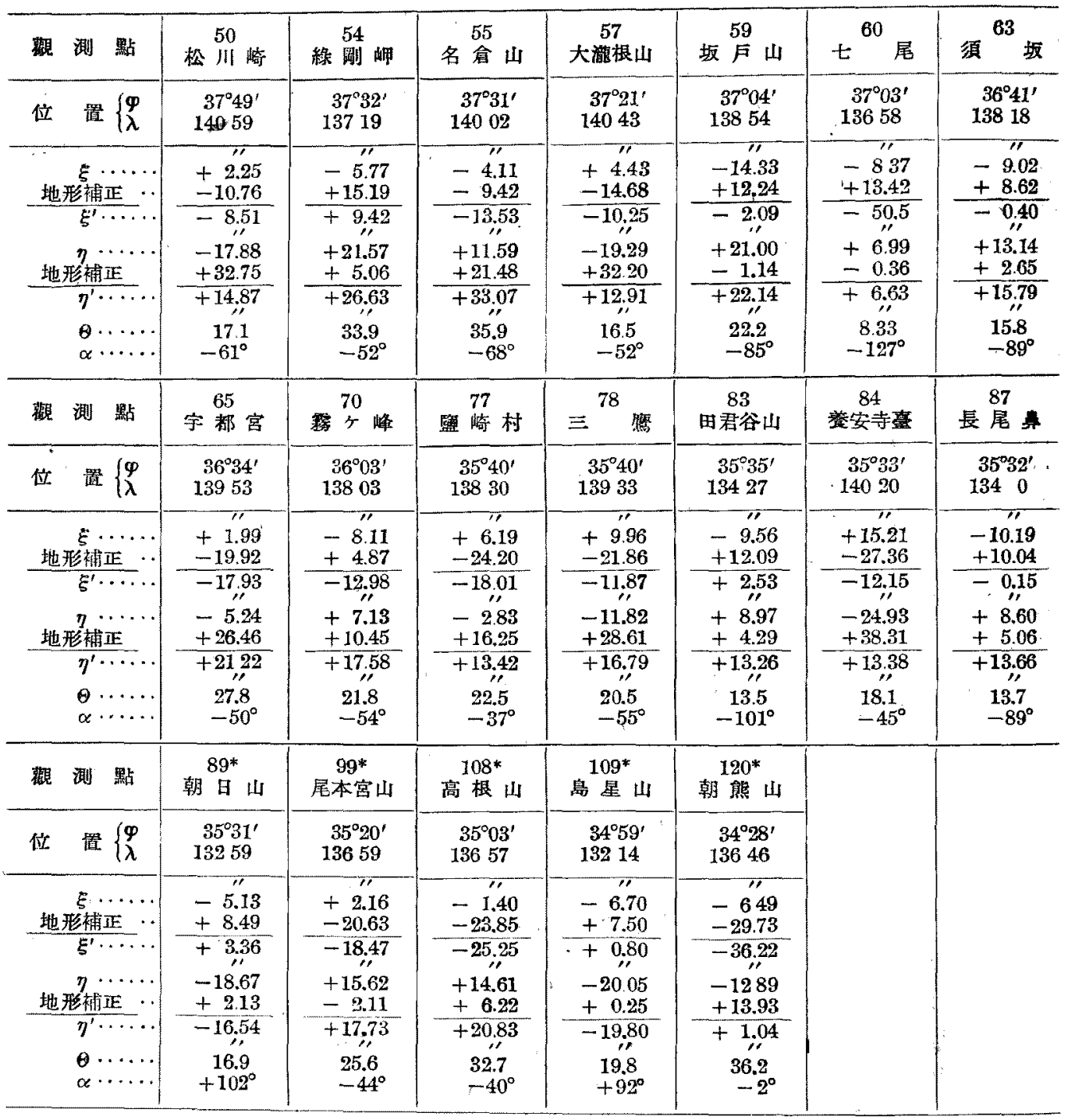

$\theta$ は $\sqrt{\xi^{\prime 2}+\eta^{\prime 2}}$ 表し，最後の行の $\alpha$ は $\alpha=\tan ^{-1} \frac{\eta^{\prime}}{\xi^{\prime}}$ で表される量で，偏倚量が何れの方向を向 くかを示すものである.

本表に体れば，吾々は地形の影響を今迄考一來つたような假定に基いて補正せる垂遖線偏倚は， 極めて顯著な系統差を有するてとを知ることが出來る。

夫れをもつと解り易くする爲に試に圖に表したものが第 3 圖である. 圖に於ける矢印しの向き

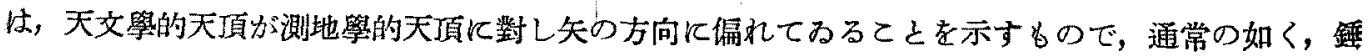
を吊り下げを場合として考へるならば，該錘の下端が矢と反㡤の方向に引かれてるるてとを意味 
し，文矢の長さは偏れの大きさ $\theta$ を代表する．之を換言すれば本州各地は概して，太本洋の方向 から强い引力を受けてるるのである.

第 3 圆

元來著者等が此處に試みた地形補正の意味は何 であつたかと言ふと，既述せる如く海面より高い 陸地は平均比重 2.70 の過剩質量として單に地表 上飞乘つかつてるると考へて其の引力を差引き， 及海水の部分は, 平均比重一 1.67 の缺損質量が海 の表面から海底面まで存在すると考へ，其の引力 を補填したのである．即ち觀測點の周圍 $1000 \mathrm{~km}$ の遠方迄山当谷も無く，又海多なく，一望の平原 が遠く連り，且つ丈地下の構造は一樣で密度は何 處でも一定と考入た場合に觀測さるべき偏倚量を

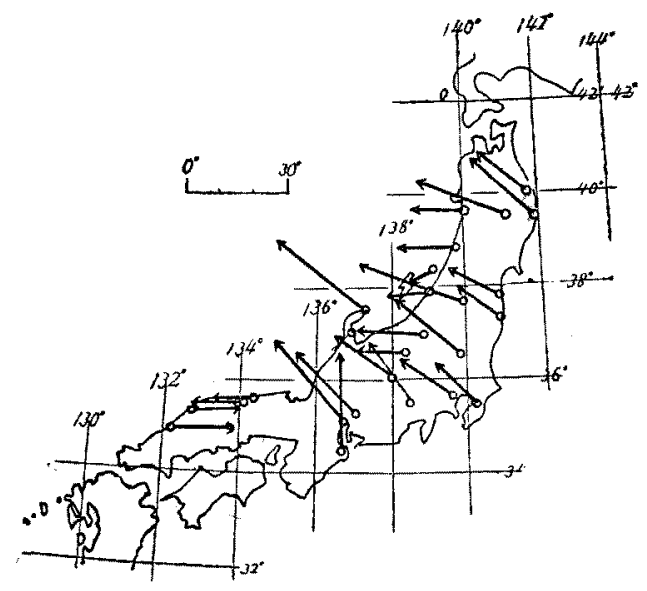
求めることに他ならなかつれ. 若し此の假定がよく事實に近いならば，換言すれば地下構造が真賽 一樣で，地殸內密度は地心を中心として棈圓層狀に分布し，日本海より滛か日本海溝に及ぶ全地域 に於て，水本の方向には少しも不規則な分布が存在しないならば，地形の影響を補正しを垂直線偏 㥓毁ち第 3 圖の偏倚量は向をに於ても大きさに於ても不規則な偶然的分布をなすか或は全く零とな るべき性質を有してわる䇢である. 然るに事實は之に区して，常に太平洋の方向から引き付けられ る樣斿引カが殘留するのである．此の事實は極めて重要な事柄であつて，確かに本州太平洋方面の 海底物質は日本海方面の海底物質に比較して相對的に密度が大なるととを示すものである.䧽つて， 太平洋の深さは一般に日本海の樑さよりも，概して深きに想到すれば地款均衡說に述へられて居る 上うな機巧が，ともかく本邦の近傍に於ても亦成立して居ると推論するてとが出來る. 然し乍ら斯 くの如き機巧を考入ることに位つて，どの程度まで正しく事實を說明するてとが出來るか，之を諸 外國，例人ば印度，アメリカ等の場合に較べて，尚一層上く成立して居るか，或は其の反對である かといふ上うな事は此處では今は何も解らない. 然し何れにしても本邦近傍に於ても，斯くの如き 機巧が成立してみること丈は確かで西る。

\section{3. 均衡面の深さの決定}

そてで罍然次问問題となるのは，然らば均衡面の㳭さは幾ら位であらうかといふととである，そ れが深いと淺いとでは地殼內此重分布に自ら輕重があるべき筈である. 更に進んで問題となるの は，斯くして求められれ场衡面の深さに相當する補正老計算し所謂均衡補正老第 3 圖に加へえなら 壮どのような剩䤣が殘るであらうかといふととである．次に此等の問題を若干調べてみよう.

今概念を出來る丈單純にして置く爲に地表附近の過剩或は缺損質量は平均海面から此の均衡面迄 


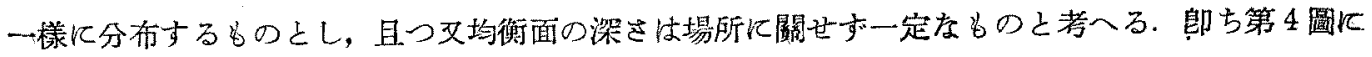
於て, 平均海面から，樑さ $T$ までの閒分布せしめるべき補償物質の密度は單飞 $h_{0}$ 友る地形の みに依つて定まり，當該地殼柱內では深さに無閵係に海面附近でb，

第 4 圆

深さ $T$ の附近でも同一であるとする.斯くす就ば，均衡の補正は

（4）と金く同榡にして

$$
\Sigma \doteqdot\left[\frac{T+H_{n}}{\sqrt{1+\left(\frac{T+H_{0}}{a}\right)^{2}}}+\frac{H_{n}}{\sqrt{1+\left(\frac{H_{1}}{a}\right)^{2}}}\right]
$$

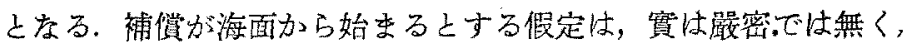

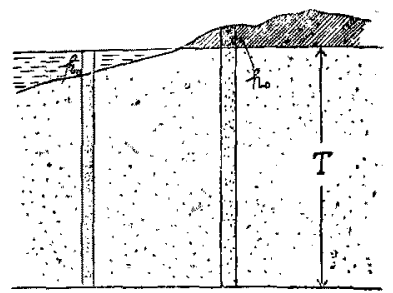

實際海底の場合の如きに於ては海底面から始まるとすべきではするが，實際に於ては $T$ は山の高 さ或は海の深さに較べれば非常に大きいと考へられるから，此のような假定に立脚して計算して 女，結果汸於て大なる誤差考生亦るとは考へられない。

そこで今 $T$ を順次に $20,40,60,80,100,120,140,160,240,320 \mathrm{~km}$ として上式て補正老計算し，

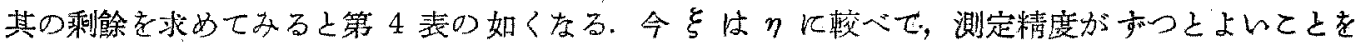

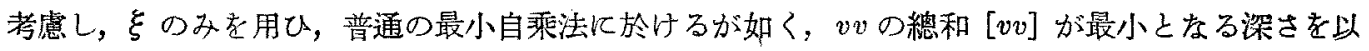

第 4 表

\begin{tabular}{|c|c|c|c|c|c|c|c|c|c|c|c|c|}
\hline \pm 0 & \multicolumn{3}{|c|}{ 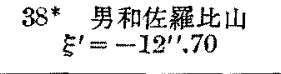 } & \multicolumn{3}{|c|}{$\begin{array}{l}40 \text { 赤 } \quad \text { 山 } \\
\xi^{\prime}=-0^{\prime} .37\end{array}$} & \multicolumn{3}{|c|}{$\begin{array}{c}40^{*}+三 \text { 种山 } \\
\xi^{\prime}=-19^{\prime \prime} .03\end{array}$} & \multicolumn{3}{|c|}{44 飯 盛 山 } \\
\hline$T \mathrm{~km}$ & $\begin{array}{l}\text { 均 衡 } \\
\text { 補 正 }\end{array}$ & $v$ & $v v$ & $\begin{array}{l}\text { 等衡 } \\
\end{array}$ & $v$ & $v v$ & $\begin{array}{l}\text { 匀衡 } \\
\text { 正 } \\
\end{array}$ & $v$ & $v v$ & 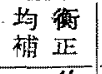 & $v$ & $v v$ \\
\hline $\begin{array}{r}20 \\
40 \\
60 \\
80 \\
100 \\
120 \\
140 \\
160 \\
240 \\
320\end{array}$ & $\begin{array}{l}+4.44 \\
+538 \\
+5.88 \\
+6.28 \\
+6.58 \\
+6.74 \\
+6.84 \\
+6.90 \\
+6.87 \\
+6.59\end{array}$ & $\begin{array}{l}-8.26 \\
-7.40 \\
-6.82 \\
-642 \\
-6.12 \\
-5.96 \\
-5.86 \\
-5.80 \\
-583 \\
-6.11\end{array}$ & $\begin{array}{l}54.76 \\
46.51 \\
41.22 \\
37.45 \\
35.52 \\
34.34 \\
33.64 \\
33.99 \\
37.38\end{array}$ & $\begin{array}{l}-1.51 \\
-1.46 \\
-1.26 \\
-1.04 \\
-0.79 \\
-0.53 \\
-0.28 \\
-0.05 \\
-0.73 \\
-1.25\end{array}$ & $\begin{array}{l}-1.88 \\
-183 \\
-1.63 \\
-1.41 \\
-1.16 \\
-0.90 \\
-0.65 \\
-0.42 \\
-0.10 \\
-1.62\end{array}$ & $\begin{array}{l}0.4 \\
0.1 \\
0 \\
2.6\end{array}$ & $\begin{array}{l}16.45 \\
15.62 \\
15.12 \\
14.71 \\
14.35 \\
14.02 \\
13.80 \\
13.40 \\
12.24 \\
11.20\end{array}$ & $\begin{array}{l}-2.58 \\
-3.41 \\
-3.91 \\
-4.32 \\
-4.68 \\
-5.01 \\
-5.28 \\
-5.68 \\
-6.79 \\
-7.83\end{array}$ & $\begin{array}{l}36 \\
89 \\
69 \\
60 \\
10 \\
85 \\
0 \\
0 \\
10 \\
11\end{array}$ & $\begin{array}{l}-5.32 \\
-482 \\
-4.27 \\
-3.75 \\
-3.26 \\
-2.83 \\
-2.43 \\
-2.07 \\
-093 \\
-0.16\end{array}$ & $\begin{array}{l}-4.87 \\
-4.34 \\
-3.79 \\
-3.27 \\
-2.78 \\
-2.35 \\
-1.95 \\
-1.59 \\
-045 \\
+0.32\end{array}$ & $\begin{array}{l}23.72 \\
18.84 \\
4.36 \\
1.69 \\
7.73 \\
5.52 \\
3.80 \\
2.53 \\
0.20 \\
0.10\end{array}$ \\
\hline 表より & \multicolumn{3}{|c|}{ 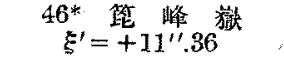 } & \multicolumn{3}{|c|}{ 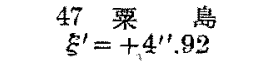 } & \multicolumn{3}{|c|}{$\begin{array}{c}48 \text { 松 }{ }^{5} \text { 崎 } \\
\xi^{\prime}=+1{ }^{\prime \prime} .23\end{array}$} & \multicolumn{3}{|c|}{ 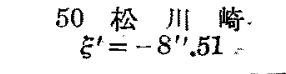 } \\
\hline$T \mathrm{~km}$ & $\begin{array}{l}\text { 均衡 } \\
\text { 補正 } \\
\end{array}$ & $v$ & $v v$ & $\begin{array}{l}\text { 均衙 } \\
\text { 禣正 }\end{array}$ & $\tau^{*}$ & $v v$ & $\begin{array}{l}\text { 均矢 } \\
\text { 補正 } \\
\end{array}$ & $v$ & $v v$ & $\begin{array}{l}\text { 均衙 } \\
\text { 袺正 }\end{array}$ & $v$ & $v v$ \\
\hline $\begin{array}{r}20 \\
40 \\
60 \\
80 \\
100 \\
120 \\
140 \\
160 \\
240 \\
320\end{array}$ & $\begin{array}{r}+10.89 \\
+10.48 \\
+10.16 \\
+9.88 \\
+9.62 \\
+9.39 \\
+9.18 \\
+8.98 \\
+8.27 \\
+7.67\end{array}$ & $\begin{array}{l}-0.47 \\
-0.88 \\
-1.20 \\
-1.48 \\
-1.74 \\
-1.97 \\
-2.18 \\
-2.38 \\
-3.09 \\
-3.69\end{array}$ & $\begin{array}{r}0.22 \\
0.77 \\
1.44 \\
219 \\
3.08 \\
3.88 \\
4.75 \\
5.66 \\
9.55 \\
13.62\end{array}$ & $\begin{array}{l}-8.90 \\
-8.09 \\
-7.36 \\
-6.69 \\
-6.07 \\
-5.50 \\
-4.97 \\
-4.49 \\
-2.95 \\
-1.88\end{array}$ & $\begin{array}{l}-3.98 \\
-3.17 \\
-2.44 \\
-1.77 \\
-1.15 \\
-0.58 \\
-0.05 \\
+0.43 \\
+1.97 \\
+3.04\end{array}$ & $\begin{array}{l}5.95 \\
3.13 \\
1.32 \\
0.34 \\
0.00 \\
0.18 \\
388 \\
9.24\end{array}$ & $\begin{array}{l}-6.79 \\
-6.06 \\
-5.33 \\
-4.66 \\
-4.04 \\
-3.49 \\
-2.99 \\
-2.55 \\
-1.18 \\
-0.30\end{array}$ & $\begin{array}{l}-5.56 \\
-4.83 \\
-4.10 \\
-3.43 \\
-2.81 \\
-2.26 \\
-1.76 \\
-1.32 \\
-0.05 \\
-093\end{array}$ & $\begin{array}{r}10.81 \\
11.76 \\
7.90 \\
5.11 \\
3.10 \\
1.74 \\
0.10 \\
0.86\end{array}$ & $\begin{array}{r}+11.11 \\
+11.29 \\
+11.32 \\
+11.26 \\
+11.14 \\
+10.99 \\
+10.82 \\
+10.65 \\
+9.86 \\
+9.10\end{array}$ & $\begin{array}{l}+2.60 \\
+2.78 \\
+2.81 \\
+2.75 \\
+2.63 \\
+2.48 \\
+2.31 \\
+2.14 \\
+1.35 \\
+0.59\end{array}$ & $\begin{array}{l}6.76 \\
7.73 \\
7.90 \\
7.56 \\
6.92 \\
6.15 \\
5.34 \\
4.58 \\
1.82 \\
0.35\end{array}$ \\
\hline
\end{tabular}




\begin{tabular}{|c|c|c|c|c|c|c|c|c|c|c|c|c|}
\hline 第 3 表より & \multicolumn{3}{|c|}{ 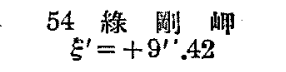 } & \multicolumn{3}{|c|}{ 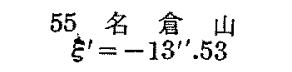 } & \multicolumn{3}{|c|}{$\begin{array}{c}57 \text { 大瀧根山 } \\
\xi^{\prime}=-10^{\prime} .25\end{array}$} & \multicolumn{3}{|c|}{ 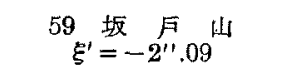 } \\
\hline$T \mathrm{~km}$ & $\begin{array}{l}\text { 芶行 } \\
\text { 補正 } \\
\end{array}$ & $v$ & $v v$ & $\begin{array}{l}\text { 均微 } \\
\text { 補正 } \\
\end{array}$ & $v$ & $v v$ & 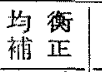 & $v$ & $v v$ & $\begin{array}{l}\text { 均渒 } \\
\text { 補正 }\end{array}$ & $v$ & $v v$ \\
\hline $\begin{array}{r}20 \\
40 \\
60 \\
80 \\
100 \\
120 \\
140 \\
160 \\
240 \\
320\end{array}$ & $\begin{array}{r}11 \\
-13.00 \\
-12.93 \\
-12.11 \\
-11.27 \\
-10.45 \\
-9.67 \\
-9.04 \\
-8.27 \\
-6.47 \\
-4.57\end{array}$ & $\begin{array}{l}-3.58 \\
-3.51 \\
-2.69 \\
-1.85 \\
-1.03 \\
-0.25 \\
+0.38 \\
+1.15 \\
+2.95 \\
+4.85\end{array}$ & $\begin{array}{r}12.82 \\
12.32 \\
7.24 \\
3.49 \\
1.06 \\
0.06 \\
0.14 \\
1.32 \\
8.70 \\
23.52\end{array}$ & $\begin{array}{l}+11.38 \\
+8.80 \\
+8.60 \\
+8.51 \\
+8.46 \\
+8.39 \\
+8.33 \\
+8.26 \\
+7.93 \\
+7.54\end{array}$ & $\begin{array}{l}11 \\
-4.25 \\
-4.73 \\
-4.93 \\
-5.02 \\
-5.07 \\
-5.14 \\
-5.20 \\
-5.27 \\
-5.60 \\
-5.99\end{array}$ & $\begin{array}{l}18.06 \\
22.37 \\
24.30 \\
25.20 \\
\mathbf{2 5 . 7 0} \\
26.42 \\
27.04 \\
27.77 \\
31.36 \\
35.88\end{array}$ & $\begin{array}{l}11 \\
+15.75 \\
+14.75 \\
+14.25 \\
+13.83 \\
+13.46 \\
+13.09 \\
+12.75 \\
+12.41 \\
+11.36 \\
+10.12\end{array}$ & $\begin{array}{l}+5.50 \\
+4.50 \\
+4.00 \\
+3.58 \\
+3.21 \\
+2.84 \\
+2.50 \\
+216 \\
+1.11 \\
-0.13\end{array}$ & $\begin{array}{r}30.25 \\
20.25 \\
16.00 \\
1282 \\
10.30 \\
807 \\
6.25 \\
4.67 \\
1.23 \\
0.02\end{array}$ & $\begin{array}{r}\prime \\
-8.22 \\
-5.33 \\
-3.53 \\
-2.28 \\
-1.26 \\
-0.48 \\
+0.15 \\
+0.68 \\
+2.08 \\
+2.77\end{array}$ & $\begin{array}{r}-10.31 \\
-7.42 \\
-5.62 \\
-4.32 \\
-3.35 \\
-2.57 \\
-1.94 \\
-1.41 \\
-0.01 \\
+0.68\end{array}$ & $\begin{array}{r}106.30 \\
55.06 \\
31.58 \\
18.66 \\
11.22 \\
6.60 \\
3.76 \\
1.99 \\
0.00 \\
0.46\end{array}$ \\
\hline 第 3 表より & \multicolumn{3}{|c|}{$\begin{array}{c}60 \quad \begin{array}{l}t \\
\xi^{\prime}\end{array}=+5^{\prime \prime} .05\end{array}$} & \multicolumn{3}{|c|}{$\begin{array}{l}63 \text { 須 坂 } \\
\xi^{\prime}=-0^{\prime \prime} .40\end{array}$} & \multicolumn{3}{|c|}{$\begin{array}{c}65 \text { 宇 都 宮 } \\
\xi^{\prime}=-17^{\prime \prime} .92\end{array}$} & \multicolumn{3}{|c|}{$\begin{array}{c}70 \text { 霧 } \xi^{\prime \prime} \text { 敗 } \\
\xi^{\prime}=-12^{\prime \prime} .98\end{array}$} \\
\hline$T \mathrm{~km}$ & $\begin{array}{l}\text { 均衡 } \\
\text { 補正 } \\
\end{array}$ & $v$ & $v v$ & $\begin{array}{l}\text { 均衡 } \\
\text { 粗正 } \\
\end{array}$ & $v$ & $v v$ & $\begin{array}{l}\text { 均衡 } \\
\text { 糂正 } \\
\end{array}$ & $v$ & $v v$ & $\begin{array}{l}\text { 均衡 } \\
\text { 補 正 }\end{array}$ & $v$ & $v v$ \\
\hline $\begin{array}{r}20 \\
40 \\
60 \\
80 \\
100 \\
120 \\
140 \\
160 \\
240 \\
320\end{array}$ & $\begin{array}{r}-12.22 \\
-11.51 \\
-10.73 \\
-9.91 \\
-9.11 \\
-8.34 \\
-7.64 \\
-6.98 \\
-4.11 \\
-3.67\end{array}$ & $\begin{array}{l}-7.17 \\
-6.46 \\
-5.68 \\
-4.86 \\
-4.06 \\
-3.29 \\
-2.59 \\
-1.93 \\
+0.94 \\
+1.38\end{array}$ & $\begin{array}{r}51.41 \\
41.73 \\
32.26 \\
23.62 \\
16.48 \\
10.82 \\
6.71 \\
3.72 \\
0.88 \\
1.90\end{array}$ & $\begin{array}{l}-6.87 \\
-5.38 \\
-4.40 \\
-3.21 \\
-2.37 \\
-1.65 \\
-1.05 \\
-0.55 \\
+0.82 \\
+1.58\end{array}$ & $\begin{array}{l}-7.27 \\
-5.78 \\
-4.80 \\
-3.61 \\
-2.77 \\
-2.05 \\
-1.45 \\
-0.95 \\
+0.42 \\
+1.13\end{array}$ & $\begin{array}{r}52.85 \\
33.41 \\
23.04 \\
13.03 \\
7.67 \\
4.20 \\
2.10 \\
0.90 \\
0.18 \\
1.28\end{array}$ & $\begin{array}{l}+18.78 \\
+17.40 \\
+1634 \\
+15.47 \\
+14.75 \\
+14.13 \\
+18.59 \\
+13.10 \\
+11.51 \\
+10.27\end{array}$ & $\begin{array}{l}+0.86 \\
-0.52 \\
-1.58 \\
-2.45 \\
-3.17 \\
-3.79 \\
-4.33 \\
-4.82 \\
-6.41 \\
-7.65\end{array}$ & $\begin{array}{r}0.74 \\
0.27 \\
2.50 \\
6.00 \\
10.05 \\
14.36 \\
18.75 \\
23.23 \\
41.09 \\
58.52\end{array}$ & $\begin{array}{l}+7.33 \\
+7.34 \\
+7.46 \\
+7.55 \\
+7.58 \\
+7.57 \\
+7.53 \\
+7.47 \\
+6.10 \\
+6.65\end{array}$ & \begin{tabular}{l|}
-5.65 \\
-5.64 \\
-5.58 \\
-5.43 \\
-5.40 \\
-5.41 \\
-5.45 \\
-5.51 \\
-6.88 \\
-6.33
\end{tabular} & $\begin{array}{l}31.92 \\
37.81 \\
30.47 \\
29.48 \\
29.16 \\
29.27 \\
29.70 \\
30.36 \\
47.33 \\
40.07\end{array}$ \\
\hline 第 3 表より & \multicolumn{3}{|c|}{ 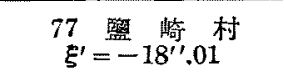 } & \multicolumn{3}{|c|}{$\begin{array}{l}78 \equiv=11^{\prime 2} \\
\xi^{\prime}=-11^{\prime \prime .87}\end{array}$} & \multicolumn{3}{|c|}{ 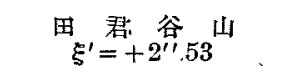 } & \multicolumn{3}{|c|}{$\begin{array}{c}\text { 荃安寺营 } \\
\xi^{\prime}=-12^{\prime \prime} .15\end{array}$} \\
\hline$T \mathrm{~km}$ & $\begin{array}{l}\text { 均衡 } \\
\text { 補 正 } \\
\end{array}$ & $v$ & $v v$ & $\begin{array}{l}\text { 均衖 } \\
\text { 補 正 } \\
\end{array}$ & $v$ & $v v$ & $\begin{array}{l}\text { 均衡 } \\
\text { 袢正 } \\
\end{array}$ & $p$ & $w$ & 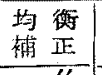 & $v$ & $v v$ \\
\hline $\begin{array}{r}20 \\
40 \\
60 \\
80 \\
100 \\
120 \\
140 \\
160 \\
240 \\
320\end{array}$ & $\begin{array}{r}+21.57 \\
+19.51 \\
+18.23 \\
+17.21 \\
+16.38 \\
+15.64 \\
+14.98 \\
+14.39 \\
+11.60 \\
+10.56\end{array}$ & $\begin{array}{l}+3.56 \\
+1.50 \\
+0.22 \\
-0.80 \\
-1.63 \\
-2.37 \\
-3.03 \\
-3.62 \\
-6.41 \\
-7.45\end{array}$ & $\begin{array}{r}12.67 \\
2.25 \\
0.05 \\
0.64 \\
2.66 \\
5.62 \\
9.18 \\
13.10 \\
41.09 \\
41.60\end{array}$ & $\begin{array}{r}+21.69 \\
+21.21 \\
+20.62 \\
+19.98 \\
+19.32 \\
+18.67 \\
+18.05 \\
+17.44 \\
+15.30 \\
+13.55\end{array}$ & $\begin{array}{l}+9.82 \\
+9.34 \\
+8.75 \\
+8.11 \\
+7.45 \\
+6.80 \\
+6.18 \\
+5.57 \\
+3.43 \\
+1.68\end{array}$ & $\begin{array}{r}96.43 \\
87.24 \\
76.56 \\
65.77 \\
5550 \\
46.24 \\
38.19 \\
31.02 \\
11.76 \\
2.82\end{array}$ & $\begin{array}{l}-8.59 \\
-6.12 \\
-4.42 \\
-2.97 \\
-2.32 \\
-1.59 \\
-1.00 \\
-0.49 \\
-0.85 \\
-1.51\end{array}$ & $\begin{array}{l}-6.06 \\
-3.59 \\
-1.89 \\
-0.44 \\
+0.21 \\
+0.94 \\
+1.53 \\
+2.04 \\
+1.68 \\
+1.02\end{array}$ & $\begin{array}{r}36.72 \\
12.89 \\
3.57 \\
0.19 \\
0.04 \\
0.88 \\
2.34 \\
4.16 \\
2.82 \\
1.04\end{array}$ & $\begin{array}{r}+26.92 \\
+26.19 \\
+25.36 \\
+24.47 \\
+23.56 \\
+22.68 \\
+21.83 \\
+21.02 \\
+18.22 \\
+16.01\end{array}$ & $\begin{array}{r}-14.77 \\
-14.04 \\
-13.21 \\
-12.32 \\
-11.41 \\
-10.53 \\
-9.68 \\
-8.87 \\
-6.07 \\
-3.86\end{array}$ & $\begin{array}{r}218.15 \\
197.12 \\
174.50 \\
151.78 \\
130.19 \\
110.88 \\
93.70 \\
78.68 \\
36.84 \\
14.90\end{array}$ \\
\hline 第 3 淁上り & \multicolumn{3}{|c|}{ 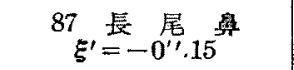 } & \multicolumn{3}{|c|}{$\begin{array}{c}89^{* *} \text { 朝 }{ }^{\text {日 }} \xi^{\prime}=+3^{\prime \prime} .36 \\
\text { 山 }\end{array}$} & \multicolumn{3}{|c|}{$\begin{array}{c}99^{*} \text { 尾本宫山 } \\
\xi^{\prime}=-18^{\prime \prime} .47\end{array}$} & \multicolumn{3}{|c|}{$\begin{aligned} 108^{*} & \text { 高 根 山 } \\
\xi^{\prime} & =-25^{\prime} .25\end{aligned}$} \\
\hline$T \mathrm{~km}$ & $\begin{array}{l}\text { 均衡 } \\
\text { 補正 }\end{array}$ & $v$ & $v v$ & $\begin{array}{l}\text { 均衡 } \\
\text { 補 正 }\end{array}$ & $v$ & $v v$ & $\begin{array}{l}\text { 竘衔 } \\
\text { 襍正 }\end{array}$ & $v$ & $v v$ & $\begin{array}{l}\text { 均衡 } \\
\text { 㢼正 }\end{array}$ & $v^{\prime}$ & $v v$ \\
\hline $\begin{array}{r}20 \\
40 \\
60 \\
80 \\
100 \\
120 \\
140 \\
180 \\
240 \\
320\end{array}$ & $\begin{array}{l}-7.54 \\
-5.59 \\
-4.23 \\
-3.20 \\
-2.79 \\
-1.72 \\
-1.16 \\
-0.68 \\
+0.65 \\
+1.41\end{array}$ & $\begin{array}{l}-7.69 \\
-5.74 \\
-4.38 \\
-3.35 \\
-2.94 \\
-1.87 \\
-1.31 \\
-0.83 \\
+0.50 \\
+1.26\end{array}$ & $\begin{array}{r}59.14 \\
32.95 \\
19.18 \\
11.22 \\
8.64 \\
3.50 \\
1.72 \\
0.69 \\
0.25 \\
1.59\end{array}$ & $\begin{array}{l}-7.83 \\
-6.62 \\
-5.63 \\
-4.81 \\
-4.07 \\
-3.49 \\
-2.96 \\
-2.49 \\
-1.08 \\
-0.19\end{array}$ & $\begin{array}{l}-4.47 \\
-3.26 \\
-2.27 \\
-1.45 \\
-0.71 \\
-0.13 \\
+0.40 \\
+0.87 \\
+2.28 \\
+3.17\end{array}$ & $\begin{array}{r}19.98 \\
10.63 \\
5.15 \\
2.10 \\
0.50 \\
0.02 \\
0.16 \\
0.76 \\
5.20 \\
10.05\end{array}$ & $\begin{array}{l}+20.42 \\
+19.19 \\
+18.18 \\
+17.30 \\
+16.51 \\
+15.79 \\
+15.15 \\
+14.56 \\
+12.63 \\
+11.15\end{array}$ & $\begin{array}{l}+1.95 \\
+0.72 \\
-0.29 \\
-1.17 \\
-1.96 \\
-2.68 \\
-3.32 \\
-3.91 \\
-5.84 \\
-7.32\end{array}$ & $\begin{array}{r}3.80 \\
0.52 \\
0.08 \\
1.37 \\
3.84 \\
7.18 \\
11.02 \\
15.29 \\
2.43 \\
53.53\end{array}$ & $\begin{array}{l}+23.70 \\
+22.90 \\
+22.19 \\
+21.36 \\
+20.55 \\
+19.77 \\
+19.02 \\
+18.32 \\
+15.89 \\
+13.98\end{array}$ & $\begin{array}{r}-1.55 \\
-2.26 \\
-3.06 \\
-3.89 \\
-4.70 \\
-5.48 \\
-6.23 \\
-6.93 \\
-9.36 \\
-11.27\end{array}$ & $\begin{array}{r}2.40 \\
5.11 \\
9.36 \\
15.13 \\
22.09 \\
30.03 \\
38.81 \\
48.02 \\
87.60 \\
105.47\end{array}$ \\
\hline
\end{tabular}




\begin{tabular}{|c|c|c|c|c|c|c|}
\hline 第 3 表より & \multicolumn{3}{|c|}{$\begin{array}{c}109^{*} \\
\xi^{\prime} \stackrel{\text { 島 }}{=}+0^{\prime \prime} .80^{\text {暑 }}\end{array}$} & \multicolumn{3}{|c|}{$\begin{array}{c}120^{*} \text { 朝 } \xi^{\prime}=-36^{\prime}{ }^{\prime} .22 \\
\text { 售 }\end{array}$} \\
\hline$T \mathrm{~km}$ & 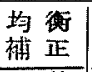 & $v$ & $v v$ & $\begin{array}{l}\text { 均衡 } \\
\text { 補正 } \\
\end{array}$ & $v^{*}$ & $v v$ \\
\hline 120 & -5.04 & -4.24 & 17.98 & $\begin{array}{c}\prime \prime \\
+32.80\end{array}$ & -3.42 & 11.70 \\
\hline 40 & -3.32 & -2.52 & 6.35 & $\begin{array}{r}+31.42 \\
\end{array}$ & $-4,80$ & 23.04 \\
\hline 60 & -2.24 & -1.44 & 207 & +30.20 & -6.02 & $36: 24$ \\
\hline 80 & -1.46 & -0.66 & 0.44 & +29.01 & -7.21 & 51.98 \\
\hline 100 & -0.86 & -0.06 & 0.00 & +27.85 & -8.37 & 70.06 \\
\hline 120 & -0.36 & +0.4 & 0.19 & +26.74 & -9.48 & 89.87 \\
\hline 140 & +1.06 & +1.86 & 3.46 & +25.68 & -10.54 & 111.09 \\
\hline 160 & -0.17 & +0.63 & 0.40 & +24.69 & -11.53 & 132.94 \\
\hline 240 & +1.46 & +2.26 & 5.11 & +21.26 & -14.96 & 223,80 \\
\hline 0 & +1.88 & +2.68 & 7.18 & +18.57 & -17.65 & 311.52 \\
\hline
\end{tabular}

て, 求める深さ $T$ と考へると， $T=120 \mathrm{~km}$ となる (第 5 圖). 郎ち均衡面の哚さは大體 $120 \mathrm{~km}$ 位 と考へられる.

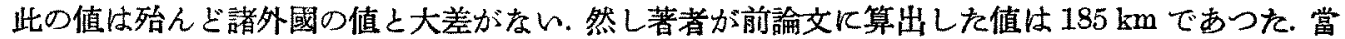
時の計算は僅かに 16 點の觀測から求めたもので、今回の值は 26 個の觀測を使用したものであると は言人，結果は可成り相違して居る. 單に計算に加ふべき觀測點の孉をてれ丈增したために，てれ位 異つた數值を得たととは，Tが數值としては未だ充分正しくはないととを意味するが,たが均衡的 補償分布が行はれて居り，且つ其の深さは大體てれ位のものであらうと言ふこと丈は言へると思ふ。

$T=120 \mathrm{~km}$ として各點に均衡補正を加へそれを前と同樣に圖上に記入せるものが第 5 表皮び第 6 圖である. 此の圖でわかることは, 均衡の機巧をで考へに入れて補正を加へても剩餘として得ら れを垂直線偏倚柱明かに本州の山岳地帶から强い引力を受けてるるのである. 而か女此の引力の方 向は極めて規則正しく，明が日本島苽に直角な成分が極めて顯著である，是は結局するとてろ，

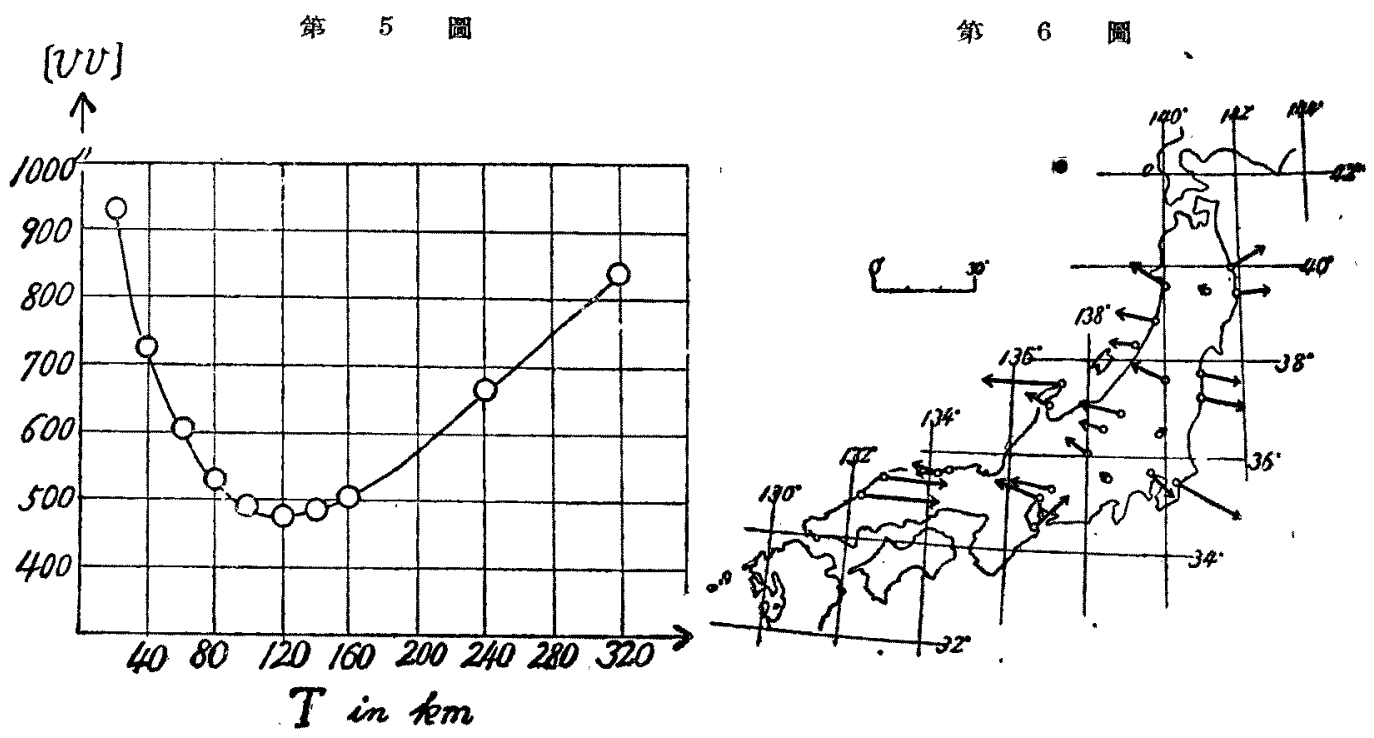




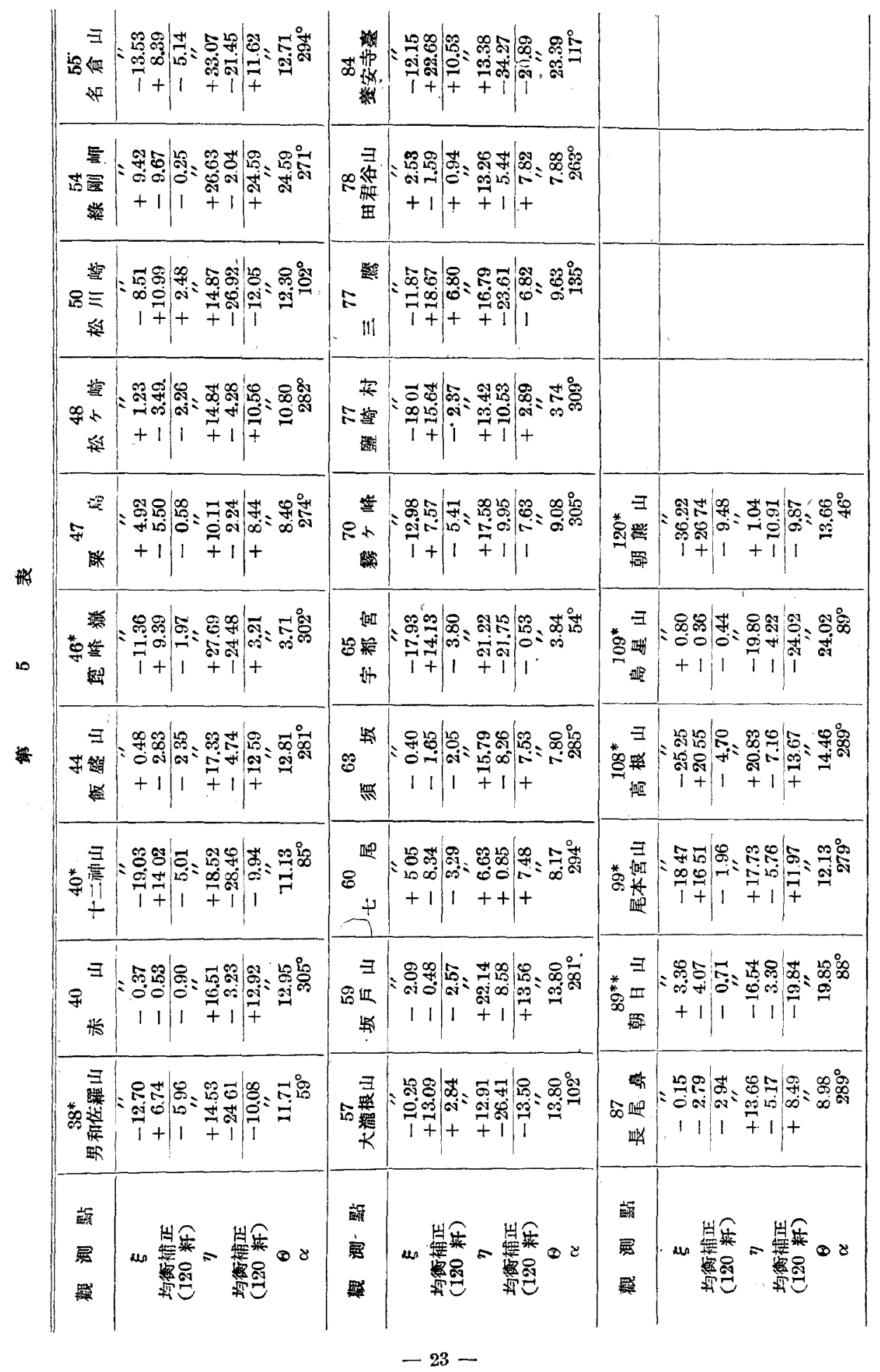


本州近傍の地下構造戊部的飞は非常に複雜であつても，大局から見ると極めて單純であって大き

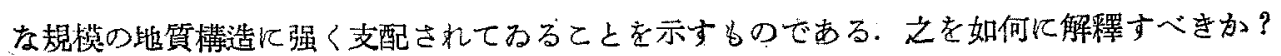

解釋の方法はいくらでもあるであらう。强ひて之を均衡面の深さの不均一として解釋するならば，

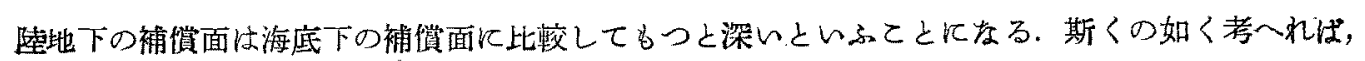

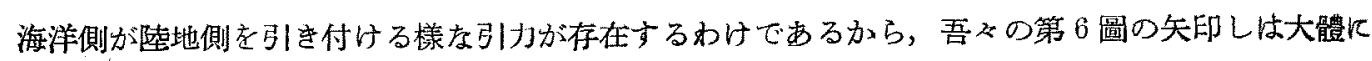

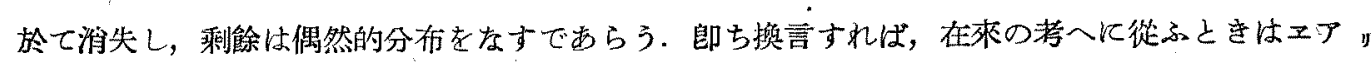
一の如く考へた方がもつとょく日本の地下構造をあらはすと考へ得られるのである. 然し作ら之は 單に一つの見方にすを゙ない，吾々は㭪偳密度が海面から均一飞分布すると假定したのであるが，此 の假定は實際には自然でない，叙上の剩餘を消失せしめる如を補償密度分布法則をこそ寧ろ追求す ペきであらうと考へる.

\section{4. 結論}

垂直楾偏倚加測地學的系統差を除を，更に地形の補正を加入ると，本邦に於ても亦地殼均衡の 假說があてはまつて居るととがわかる．均衡面をプラットの如く考へると其の深さは大體 $120 \mathrm{~km}$ 位之推定せられる. 然し乍ら $120 \mathrm{~km}$ の均衡補正を加へると，本州山岳地帶に引かる小引力が，小

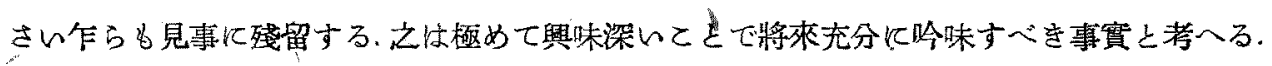

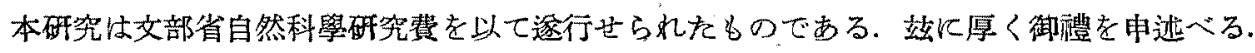

\section{雪の結晶の生成條件についで}

花島 政 人**

\section{§1、緒 霉}

既に北海道帝國大學理學部紀慗の「雪の研究」第 11 報》に於て，雪の人工的生成が研究され，そ の中て雪の結晶形㐊との生成條件との關係が調へられてるる。そこでは結晶形の分類の中で數種の 本面結晶が單に樹枝狀緢晶として分類されてるるので，その生成條件も近似的なるのになってるる. 即ち前に樹枝狀結晶として取扱はれてみた各種の平面結晶の中で，その外形は互にかなり似てるる のであるが，生成條件は相當にちがつてわるものがあることが，其の後の研究によつて判明しま.

それでこの實驗で樹枝狀結晶の形を先づ詳しく定め，之れの生成の外的條件を調べた。 それk

* M. Hanazima : On the External Conditions controlling the Formation of Snow Crystals.. 北 大低溫科學研究所埌告第 6 躆.

** 北海道帝大理學部物理数室.

1）北海道帝國大學理學部紀要第 2 輯, 2 (1938) pp. 13-57, 中谷, F田, 杣山, 人工雪の研究䌅報 (英文). 